\title{
Pendampingan Pengembangan UMKM dan Sosialisasi Nabung Saham Di Desa Pandansari Kecamatan Senduro Kabupaten Lumajang
}

\author{
Muhammad Rijalus Sholihin \\ Program Studi Akuntansi, STIE Widya Gama Lumajang \\ muhammadrijalus@gmail.com
}

\begin{abstract}
Abstrak
Perkembangan teknologi informasi sudah seharusnya dipahami oleh semua lapisan masyarakat, namun pada kenyataanya tidak semua masyarakat melek akan teknologi informasi, sehing ahal ini pelu menjadi perharian khusus dalam mendampingi usaha yang digeluti oleh pelaku usaha, Tidak sedikit dari para pelaku usaha yang tidak memahami cara berinvestasi dan memasarkan produk dari usaha yang mereka jalani oleh masyarakat desa pandansari Kabupaten Lumajang, sehingga ini seakan menjadi perhatian khusus pagi para akademisi dalam mendampingi para pelaku usaha tersebut dalam memasarkan prosuk dan melakukan investasi jangka panjang dengan cara seperti yang dilakukan saat ini. Langkah yang dilakukan adalah memberikan wawasan mengenai strategi pengembangan UMKM dan nabung saham serta melakukan diskusi mengennai permasalahan dan situasi yang ada. Demi tercapainya tujuan yang utama perlu terciptanya kontinuitas dan pemahaman yang mendalam mengenai strategi pemasaran dan administrasi lainnya, sebab tanpa adanya hal tersebut dengan yang dilakukan dengan baik dan benar akan sulit tercipta tujuan utama diatas.
\end{abstract}

\section{Kata Kunci : UMKM, Saham, Investasi}

\begin{abstract}
The development of information technology should have been understood by all levels of society, but in fact not all people are literate about information technology, so this has become a special day-to-day activity in assisting businesses that are involved, not a few of them do not understand how to invest and market the products of the businesses that they live by the people of Pandansari village Lumajang Regency, so that this seems to be a special concern for the academics in assisting the business people in marketing the products and making long-term investments in the way they are today. The step taken is to provide insight into the strategy of developing MSMEs and stock saving and to discuss issues and situations. In order to achieve the main goals, the need to create continuity and deep understanding of other marketing and administrative strategies, because without these things done well and correctly, the main objectives above will be difficult to create.
\end{abstract}

Keywords: MSMEs, Stocks, Investment

\section{PENDAHULUAN}

Setiap usaha yang dilakukan oleh masyarakat sudah selayaknya mendapatkan pendampingan atas kegiatan yang merea lalukan, terlebih dlaam pengembangan usaha yang dijalani, sebab tidak sedikit masalah yang mereka hadapi pada setiap waktunya, mulai dari ekonomi permodalan, serrta sampai pemasaran hingga pola pikir yang terkadang tidak selaras dengan berbagai keadaan. 
Masalah yang dihadapi para pelaku usaha tidak sedikit, melainkan banyak sekali, termasuk masalah keuangan serta masalah pemasaran dari hasil produk atau usaha yang mereka geluti, hal ini jelas perlu adanya pendampingan maupun sosialisai atas masalah yangn mereka hadapi, terlebih masalah keuangan.

Dalam segi administrasi juga tidak sedikit pelaku usaha yang minim pengetahuan, yang didasari beberapa faktor seperti minimnya pendidikan dan terbatasnya pengetahuan ilmu ekonomi yang berkembang saat ini, terlebih didunia era digiyal seperti sekarang ini.

Perkembangan teknologi informasi sudah seharusnya dipahami oleh semua lapisan masyarakat, namun pada kenyataanya tidak semua masyarakat melek akan teknologi informasi, sehing ahal ini pelu menjadi perharian khusus dalam mendampingi usaha yang digeluti oleh pelaku usaha.

Masalah investasi terutama masalah saham juga apalagi tidak mudah mereka pahami, sehingga perlu adanya pemahaman khusus akan hal ini agar mereka tahu manfaat dari menabung saham serta berinvestasi lain, dalam waktu singkat munkin ini tidak terlalu terlihat hasilnya, namun jika dijalani secara konsisten akan besar dampaknya.

Tidak sedikit dari para pelaku usaha yang tidak memahami cara berinvestasi dan memasarkan produk dari usaha yang mereka jalani oleh masyarakat desa pandansari Kabupaten Lumajang, sehingga ini seakan menjadi perhatian khusus pagi para akademisi dalam mendampingi para pelaku usaha tersebut dalam memasarkan prosuk dan melakukan investasi jangka panjang dengan cara salah satunya seperti yang dilakukan saat ini.

Berdasarkan hasil analisis situasi mitra di atas, dapat diambil kesimpulan bahwa masyarakat desa Pandansari Kecamatan Senduro kabupaten Lumajang membutuhkan bimbingan dalam segi pengembangan UMKM serta pemasaran dan berinvestasi sebagai wujud menabung dengan hasil di masa depan yang lebih baik, tsehingga nantinya mereka lebih mudah menjalankan usaha dan mengembangkannya dan mendapatkan pelanggan banyak yang datang untuk berbisnis bersama mereka. Oleh karena itu, harus ada upaya dalam mengatasi permasalahan tersebut agar nantinya tidak terjadi permasalahan berulang yang sering mereka alami, seperti sulit memasarkan produk dan masalah berinvestasi atau menabung yang aik dan benar, dan diharapkan pendampingan ini nantinya mampu memberikan pencatatan administrasi yang lebih baik dari yang sebelumnya. Melalui program Pengabdian Kepada Masyarakat Sekolah Tinggi Ilmu Ekonomi Widya Gama Lumajang diharapkan masalah pada pelaku usaha di Desa Pandansari Kecamatan Senduro Kabupaten Lumajang bisa teratasi.

Solusi yang ditawarkan dari ketua pengusul kepada Pelaku usaha dan masyarakat desa Pandansari Kecamatan Senduro Kabupaten Lumajang dalam rangka pendampingan pengembangan UMKM dan sosialisai Nabung Saham berupa:

a. Melakukan pemberian dan wawasan mengenai dunia usaha pada era digital serta bagaimana cara baik dalam mengembangkannya dan memasarkannya, sehingga semua tujuan dalam berwirausaha dapat tercapai dengan semaksimal mungkin.

b. Pemberian wawasan mengenai nabung saham dan petingnya berivestasi dalam kurun waktu yang tidak singkat, memgingat investasi itu sangat oenting bagi setiap pelaku usaha khususnya dan masyarakat pada umunya.

c. Melakukan diskusi atas setikap permasalahn yang dihadapi guna mendapatkan soslusi dari setiap masalah yang ada, sehingga mampu mengahsilkan keberhasilan berwirausaha seperti yanng diharapkan. 
Berdasarkan permasalahan yang dihadapi mitra dalam hal ini adalah Masyarakat Desa pandansari Kecamatan Senduro Kabupaten Lumajang, maka ketua pengusul mempunyai terget yang akan didapatkan sesudah kegiatan. Adapun terget tersebut berupa:

a. Masyarakat Pandansari khususnya pelaku usaha mampu memasarkan usaha yang dimilki dengan baik dan benar secara berkala dan mandiri tanpa ada masalah yang berarti sesuai dengan apa yang diharapkan.

b. Masyarakat Pandansari khususnya pelaku usaha mampu dan mau berivestasi atau menabung guna mengembangkan usahanya, dan melakukan investasi lainnya.

Tingkat keberhasilan dari kegiatan Pengabdian Kepada Masyarakat ini dapat diukur dari target yang sudah ditentukan di atas. Alat ukurnya berupa evaluasi kepada Masyarakat Pandansari khususnya pelaku usaha itu sendiri yang beralamat di Desa Pandansari Kecamatan Senduro Kabupaten Lumajang dalam mengaplikasikan atas hasil pendampingan yang berupa memasarkan produk atau usaha yang mereka miliki. Jika pemilik masyarakat mampu mempraktekkan minimal $75 \%$ maka pengabdia msyarakat inidianggap berhasil, namun jika kurang dari ketentuan tersebut maka perlu adanya evaluasi.

\section{METODE PELAKSANAAN}

Permasalahan mitra dalam hal ini Masyarakat Desa Pandansari, Kecamatan Senduro, Kabupaten Lumajang terutama yang menyangkut masalah jual beli barang dagang secara kredit sehingga memerlukan pembukuan yang lebih baik serta para pelaku usaha pada umumnya. Oleh karena itu ketua pengusul melalui kegiatan Pengabdian Kepada Masyarakat Sekolah Tinggi Ilmu Ekonomi Widya Gama Lumajang memilih metode pemecahan masalah yang dianggap tepat yaitu berupa model pendampingan secara intensif, diskusi dan praktek. Peserta pendampingan yaitu masyarakat sekaligus pelaku usaha di Desa Pandansari Kecamata Senduro Kabupaten Lumajang.

Adanya keterbatasan pengetahuan dan keterampilan dari peserta pendampingan iniyang yaitu masyarakat dan pelaku usaha di Desa Pandansari, Kecamatan Senduro, Kabupaten Lumajang sebagai. Hal ini dikarenakan minimnya pengetahuan dan wawasan akan pemasaran diera digital dan cara berivestasi. Melalui program kegiatan Pengabdian Kepada Masyarakat ini ketua pengusul menawarkan berbagai solusi untuk mengatasi kendala tersebut di atas. Solusi tersebut yaitu dilakukannya pendampingan intensif serta diskusi mengenai permasalahan yang selama ini dialami, termasuk mengenai maslaah berivestasi melalui nabung saham secara baik dan mudah dipahami oleh pihak yang membutuhkan dalam hal ini pemilik masyarakat desa Pandansari Kecamatan Senduro kabupaten Lumajang, yaitu:

a. Pendampingan menganalisa permasalahan yang dihadapi serta mencari solusi dari permasalahan tersebut agar nantinya bisa teratasi dengan baik dan benar. Cara yang dilakukan memalui diskusi bersama antara pengusaha satu denganpengusaha lainnya serta pemberian wawasan mengenai metode pemasaran yang baik dan benar..

Adapun materi yang disampaikan dalam kegiatan ini adalah:

1) Penjelasan makna pemasaran, terlebih pada era digital dan ekonomi kreatif saat ini.

2) Diskusi antara peserta pendampingan dengan pemateri mengenai permasalahan agar nantinya dapat ditemukan solusi terbaik dan dapat diaplikasikan.

3) Diskusi mengenai hal-hal lain mengenai teknik pemasaran dan lainnya yang dirasa perlu didiskusikan.

b. Pemberian wawasan sekaligus penjelasan mengenai arti penting menabung dan berivestasi bagi kehidupan dan keberlangsungan suatu usaha baik dalam jangka pendek 
maupun jangka panjang, dalam hal ini kita lebih berfokus mengenai pemahaman hal bursa efek indonesia dan diharapkan mereka mau dan berkenan menabung saham seperti apa yang disampaikan.

Adapun materi yang disampaikan berupa:

1) Pemahaman apa itu bursa efek indonesia dan hal uyang berhubungan didalamnya termasuk mengenai nabung saham

2) Manfaat yang akan diperoleh baik dalam jangka waktu yang pendek maupun jangka panjang dari menabung saham.

3) Sesi diskusi mengenai hal nabung saham dan pemantapan akan adanya nabung saham di Indonesia.

Lebih jelasnya kegiatan Pengabdian Kepada Masyarakat yang diterapkan dalam kegiatan Pendampingan pengembangan UMKM dan Sosialisai Nabung saham Desa Pandansari Kecamatan Senduro, Kabupaten Lumajang omelalui kegiatan pendampingan pendampingan ini digambarkan dalam kerangka pemikiran. Hal ini bertujuan agar kegiatan ini lebih terarah dan sesuai dengan sasaran awal. Adapun gambar konsep penerapan dari kegiatan Pengabdian Kepada Masyarakat kepada mitra sebagai berikut:

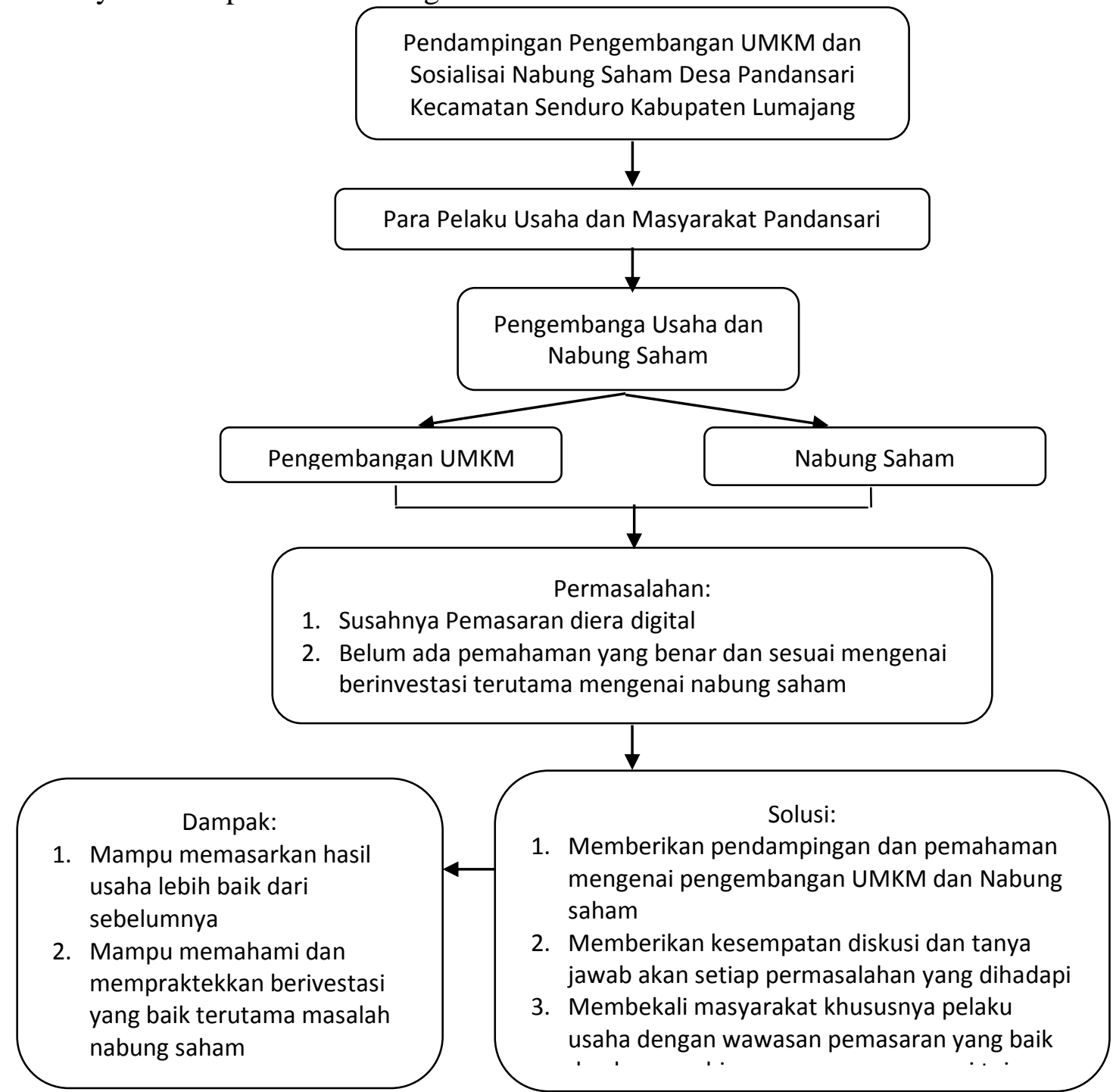

Gambar 3.1 Konsep Penerapan Kegiatan Pengabdian Kepada Masyarakat kepada Mitra 


\section{HASIL DAN PEMBAHASAN}

Berdasarkan permasalahan mitra dalam hal ini masyarakat dan pelaku usaha di Desa Pandansari, Kecamatan Senduro, Kabupaten Lumajang, maka ketua pengusul kegiatan Pengabdian Kepada Masyarakat Sekolah Tinggi Ilmu Ekonomi Widya Gama Lumajang telah melaksanakan program kegiatan yang telah disusun. Adapun kegiatan tersebut sebagai berikut:

1. Pendampingan pengembangan UMKM dan sosialisasi nabung saham bagi masyarakat dan khususnya para pengusaha di Desa Pandansari Kecamatan Senduro Kabupaten Lumajang.

Sebelum melakukan pendampingan, ada beberapa tahapan yaitu melakukan koordinasi dengan Kepala Desa Pandansari yaitu Bapak Lasmu'i yang dilaksanakan tanggal 30 Mei 2018 pukul 10.00-11.00 WIB. Bertempat dikediaman beliau Desa Pandansari, Kecamatan Senduro, Kabupaten Lumajang. Tahap selanjutnya penandatanganan kontrak dengan mitra, dilaksanakan tanggal 02 Agustus 2018 pukul 10.00 WIB bertempat kediaman Bapak Lamu'i Desa Pandansari, Kecamatan Senduro, Kabupaten Lumajang.

Pendampingan dilakukan dua tahapan sebagai berikut:

a. Pendampingan pertama dilaksanakan tanggal 04 Agustus 2018 bertempat dibalai desa Pandansari, Kecamatan Senduro, Kabupaten Lumajang. Dimulai pukul 08.00 sampai 12.00 WIB.Yang diikuti oleh masyarakat desa Pandansari. Materi yang disampaikan berupa mengenai pentingnya mengetahui dan memahami pemasaran dalam UMKM pada era milenial ini, yang diiringi dengan berkembangnya ilmu komunikasi dan digital.

b. Pendampingan kedua dilaksanakan tanggal 05 Agustus 2018 bertempat bertempat dibalai desa Pandansari, Kecamatan Senduro, Kabupaten Lumajang . Dimulai pukul 08.00 sampai 12.00 WIB. Materi yang disampaikan berupa pentingnya menabung sahamteruama bagi para pengusaha dan masyarakat pada umumnya

2. Melakuakan evaluasi dan praktek menerapkan pembukuan pengissian buku pembantu hutang sesuai dengan hasil pendampingan sebelumnya. Serta membahas mana yang kiranya masih perlu dipelajari dan diperhatikan selanjutnya.
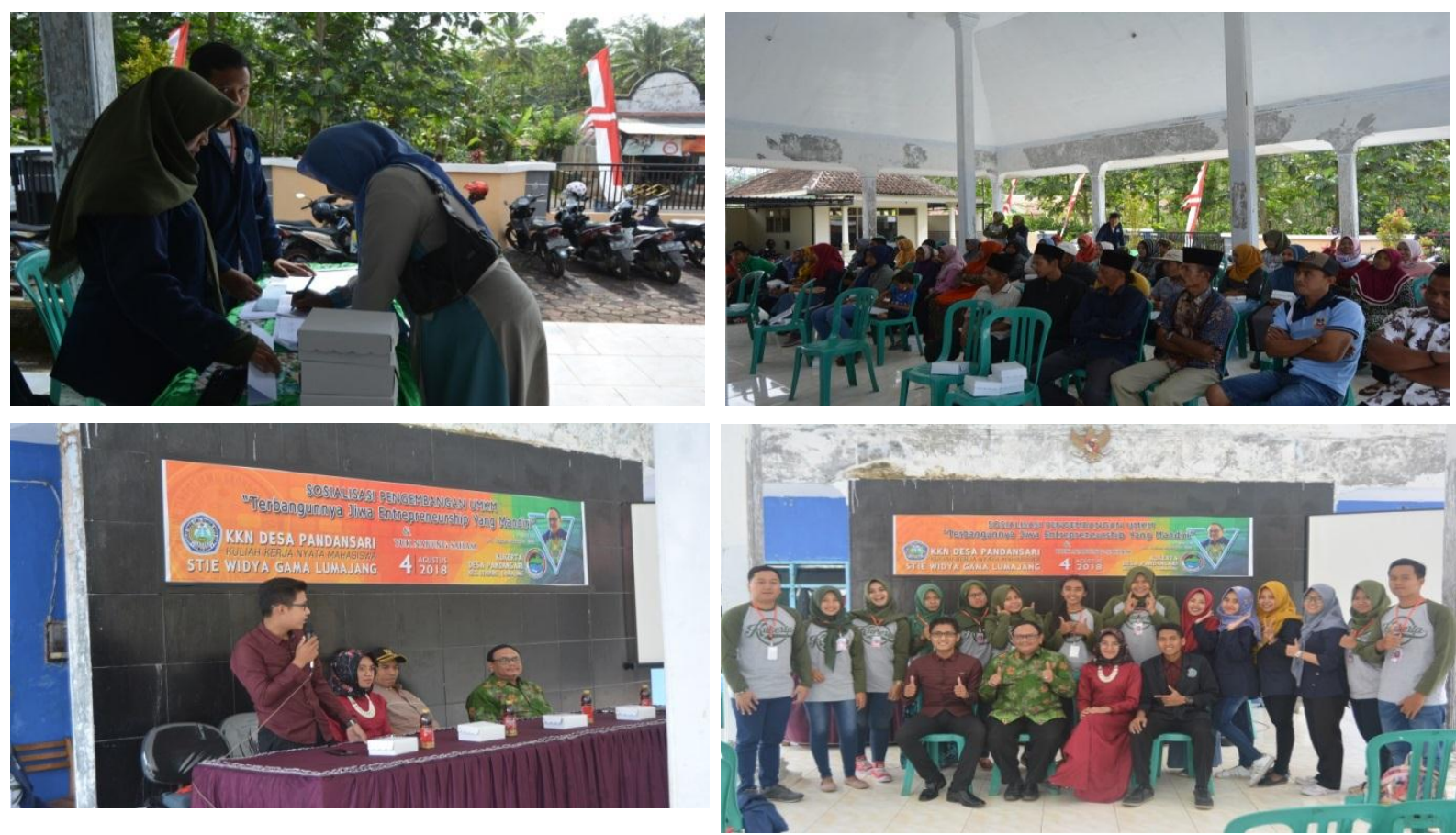


\section{KESIMPULAN}

Berdasarkan uraian di atas, kesimpulan yang dapat diambil dari kegiatan Pengabdian Kepada Masyarakat Sekolah Tinggi Ilmu Ekonomi Widya Gama Lumajang bersama mitra yaitu bertempat dibalai desa Pandansari, Kecamatan Senduro, Kabupaten Lumajang di bagi menjadi tiga kegiatan, yaitu:

a. Kegiatan Kegiatan pemberian wawasan mengenai betapa pentingnya pemasaran dan strategi pemasaran yang baik dan benar, guna mendapatkan hasil yang maksimal ditengah berkembangnya teknologi informasi yang ada saat ini, dengan demikian apa yang diharapkan bisa terealisasi dengan baik dan benar.

b. Kegiatan pemberian wawasan mengenai pentingnya dan manfaat dari menabung saham demi masa depan yang kebih baik.

c. Sesi tanya jawab mengenai permasalahan yang dihadapi oleh para pelaku usaha pada khususnya dan masyarakt Pandansari pada umumnya.

Berdasarkan uraian di atas, dapat disajikan beberapa saran demi kemajuan mitra yaitu

Desa Pandansari, Kecamatan Senduro, Kabupaten Lumajang:

a. Dibutuhkan kontinyuitas dalam melaksanakan evaluasi mengenai perkembangan strategi pemasaran yang baik dan benar, sehingga cara yang digunakan mampu menarik para calon pembeli

b. Diharapkan adanya inovasi-inovasi produk baru yang dapat menarik minat pelanggan dan mau membeli produk yang kita tawarkan, serta perlu penguasaan pasar termasuk ilmu teknologi informasi agar nantinya transaksi tidak hanya dilakukan secara offline.

\section{DAFTAR PUSTAKA}

Agung, I Gusti Ngurah. 1992. Metode Penelitian Sosial, Gramedia Pustaka Utama, Jakarta

Anindita, Ratya. 2004. Pemasaran Hasil Pertanian, Papyrus Surabaya

Irawan, Faried Wijaya, dan Sudjoni. 2001. Pemasaran: Prinsip dan Kasus, Edisi 2.

Yogyakarta: PT BPFE Yogyakarta

Kotler, Philip dan gary Armstrong, 1997, Dasar-dasar Pemasaran. Edisi Bahasa Indonesia Jilid I. Jakarta: Prehalindo

Kotler, Philips. 1997. Manajemen Pemasaran (Terjemah) Jilid I, PT Prehallindo, Jakarta

Sholihin, Muhammad Rijalus. 2018. Strategi Pemasaran Oleh Pengusaha Perempuan di kabupaten Jember, Lumajang: ASSETS Jurnal Ilmiah Ilmu Akuntansi, Keuangan dan Pajak

Sholihin, Muhammad Rijalus. 2018. Pengelolaan Keuangan Oleh Pengusaha Perempuan Pedagang Sayuran di Kecamatan Umbulsari kabupaten Jember, Lumajang: Prossiding Conference

Sholihin, Muhammad Rijalus. 2018. Pendampingan penyusunan bukupembantu hutang pada toko Zulfa Kecamatan Umbulsari Kabupaten Jember, Lumajang: Prossiding Conference 